\title{
Effectiveness of Chronic Disease Management Program in Improving “CERDIK” Healthy Behavior in Patients with Hypertension in Gunungkidul, Yogyakarta
}

\author{
Tri Puji Pangesti'), Didik Gunawan Tamtomo²), Bhisma Murti1) \\ ${ }^{1)}$ Masters Program in Public Health, Universitas Sebelas Maret \\ 2)Faculty of Medicine, Universitas Sebelas Maret
}

\section{ABSTRACT}

Background: Hypertension is the single largest contributor to the global burden of disease (GBD). The Chronic Disease Management Program (Prolanis) is a health service system and a proactive approach implemented in an integrated manner. This study aimed to determine the effectiveness of Prolanis on the "CERDIK" healthy behavior for hypertensive patients.

Subjects and Method: This cross-sectional study was conducted in hypertensive patients in 25 working areas of health centers in Gunungkidul, Special Region of Yogyakarta, from January to February 2020. A sample of 200 hypertensive patients was selected by simple random sampling. The dependent variable was the "CERDIK" healthy behavior for hypertensive patients. The independent variables were chronic disease management program (Prolanis), education level, peer support, family support, and sex. Other data were collected by using a questionnaire. Data were analyzed by path analysis using the Stata 13 application.

Results: "CERDIK" healthy behavior for hypertensive patients increased with active prolanis activity $(b=5.00 ; 95 \% \mathrm{CI}=2.80$ to $7.20 ; \mathrm{p}$
<0.001), higher education $(\mathrm{b}=1.52$; $95 \% \mathrm{CI}=$ 0.48 to $2.54 ; \mathrm{p}=0.004$ ), strong family support $(\mathrm{b}=1.38 ; 95 \% \mathrm{CI}=0.20$ to $2.57 ; \mathrm{p}=0.023)$, strong peer support $(\mathrm{b}=0.61 ; 95 \% \mathrm{CI}=-0.67$ to $2.51 ; \mathrm{p}=$ $0.352)$, and female $(\mathrm{b}=2.8 ; 95 \% \mathrm{CI}=-5.01$ to $0.64 ; \mathrm{p}=0.011)$. Education, family support, and peer support were associated with "CERDIK" healthy behavior through Prolanis.

Conclusion: "CERDIK" healthy behavior for hypertensive patients increases with active prolanis activity, higher education, strong family support, strong peer support, and female. Education, family support, and peer support were associated with "CERDIK" healthy behavior through Prolanis.

Keywords: Prolanis, "CERDIK" healthy behaviour, hypertension, path analysis

\section{Correspondence:}

Tri Puji Pangesti. Masters Program in Public Health, Universitas Sebelas Maret. Jl. Ir. Sutami 36A, Surakarta 57126, Central Java. Email: tripujipangesti8@gmail.com. Mobile: 082312657779.

Cite this as:

Pangesti TP, Tamtomo DG, Murti B (2020). Effectiveness of Chronic Disease Management Program in Improving "CERDIK" Healthy Behaviour for Hypertensive Patients in Gunungkidul, Yogyakarta. J Health Promote Behav. 05(03): 187-196. https://doi.org/10.26911/thejhpb.2020.05.03.05.

cc (i) (5) Journal of Health Promotion and Behavior is licensed under a Creative Commons cc) Attribution-Non Commercial-Share Alike 4.0 International License.

\section{BACKGROUND}

Hypertension is the single largest contributor to the global burden of disease (GBD). In recent decades, the prevalence of hypertension has increased substantially, resulting in the loss of disability-adjusted life-years (DALYs) adjusted for disability. Globally, there were 1.13 billion adults with hypertension in 2015 , compared with only 594 million in 1975 . The prevalence of hypertension increased from $17.31 \%$ in 1990 to $20.53 \%$ in 2015 , leading to an annual increase in mortality from 97.9 to 106.3 per 100,000 people and increased DALYs' loss from 95.9 million to 143 million worldwide (Yao et al., 2019). 
In Indonesia, the prevalence of hypertension is $34.1 \%$. The highest prevalence is in South Kalimantan (44.1\%), and the lowest is in Papua (22.2\%) (Basic Health Research, 2018). Meanwhile, data from the $2016 \mathrm{Na}$ tional Health Indicator Survey (Sirkesnas) shows an increase in hypertension prevalence among people aged 18 years and over by $32.4 \%$.

According to Healthcare and Social Security Agency data, the cost of hypertension services has increased every year, as much as Rp. 2.8 trillion in 2014 , Rp. 3.8 trillion in $20-$ 15, and Rp. 4.2 trillion in 2016 (Ministry of Health RI, 2018).

In 2017, according to the Yogyakarta health profile, hypertension was number one in the ten disease patterns category. Meanwhile, in the top ten, hypertension is second to diarrhea.

In Gunungkidul, hypertension has a percentage of $7.1 \%$ of the 64,239 people examined, so there are 4,562 people with hypertension. This figure is quite alarming, considering that hypertension causes stroke and cardiovascular disease (Health Office, 2017).

The Indonesian government facilitates chronic disease services in accordance with Presidential Regulation Number 12 of 2013 concerning Health Insurance (article 21 paragraph 1), one of the benefits obtained by Healthcare and Social Security Agency participants are promotive and preventive health services, one of which is Prolanis.

The Chronic Disease Management Program (Prolanis) is a health service system and a proactive approach implemented in an integrated manner involving Participants, Health Facilities and Healthcare and Social Security Agency in the context of health care for Healthcare and Social Security Agency participants who suffer from chronic diseases to achieve optimal quality of life at the cost of health services effective and efficient.
Prolanis' goal is to encourage participants with chronic diseases to achieve optimal quality of life with an indicator that $75 \%$ of registered participants who visit the First Level Health Facilities have "good" results on specific examinations of Type $2 \mathrm{DM}$ and Hypertension according to the relevant Clinical Guidelines so that they can prevent disease complications (Healthcare and Social Security Agency, 2015).

\section{SUBJECTS AND METHOD}

\section{Study Design}

This study was an analytical observational study with a cross-sectional design. The study was conducted at 25 community health centers in Gunungkidul, Yogyakarta, from January to February 2020.

\section{Population and Sample}

This study's population was hypertension patients. A sample of 200 patients was selected by simple random sampling.

\section{Study Variables}

The dependent variable was "CERDIK" healthy behavior. The independent variables were the chronic disease management program (Prolanis), education, peer support, family support, and sex.

\section{Operational Definition of Variables} "CERDIK" Healthy Behavior was a term that refers to conduct regular health checks, get rid of cigarette smoke, exercise diligently, have a balanced diet, get enough rest, and manage stress well. The instrument used was a questionnaire. The data scale was continuous, but changed to a dichotomy, coded $\mathrm{o}=$ Did not conduct "CERDIK" Healthy Behavior ( $<$ mean) and $1=$ conducted "CERDIK" healthy behavior ( $\geq$ mean).

Prolanis was a health service program and a proactive approach that was implemented in an integrated manner that involves Participants, Health Facilities, and Healthcare and Social Security Agency in the context of health care for Healthcare and Social Security 
Agency participants who suffer from chronic diseases to achieve optimal quality of life with cost-effective and efficient health services. The instrument used was the Checklist sheet, the categorical data scale, coded $0=$ Inactive ( $<2$ followed activities) $1=$ Active $(\geq$ 2 followed activities)

Education was a formal level of education completed by study subjects based on the last diploma they have. The measurement tool used a questionnaire with a categorical data scale, coded $\mathrm{o}=$ Low $(<$ Senior high school) $1=$ High ( $\geq$ Senior high school).

Peer support was a form of assistance provided by peer groups to individuals to feel comfortable and appreciated. The instrument used was a questionnaire. The data scale was continuous, but for data analysis, it was changed to dichotomy, coded $o=$ weak support ( $<$ Mean) $1=$ strong support ( $\geq$ Mean).

Family support was the family's support to hypertensive patients, which was reward support, informative support, emotional support, and instrumental support. The measurement instrument used a questionnaire. The data scale was continuous, but for data analysis, it was changed to dichotomy, coded $\mathrm{o}=$ weak support $(<$ Mean), $1=$ strong support $(\geq$ Mean).

Sex was biological characteristics seen from outward appearance. The instrument used was a questionnaire. Categorical data scale, coded $0=$ Male $1=$ Female .

\section{Data Analysis}

a. Univariate Analysis

Univariate analysis was performed on each study variable. Frequency distribution tables described categorical data. A continuous sample of data characteristics were described in terms of the parameters $\mathrm{n}$, mean, $\mathrm{SD}$, minimum, and maximum.

b. Bivariate Analysis

The bivariate analysis in this study used the chi-square test. This test was to find out how much effect the variables $\mathrm{X}$ and $\mathrm{Y}$ have.

c. Multivariate Analysis

Multivariate analysis was used to determine the effect of various variables studied using Path Analysis with the Stata 13 application.

\section{Research Ethic}

This research was conducted based on research ethics, namely, informed consent, anonymity, confidentiality, and ethical research. Research ethics was obtained from the Health Research Ethics Committee at Dr. Moewardi, Surakarta, Indonesia, No. 1,393 / XII / HREC / 2019.

\section{RESULTS}

\section{Sample Characteristics}

Table 1 shows the sample characteristics (continuous data). Table 1, the average score of "CERDIK" healthy behavior was 31.87. The mean score of Prolanis was 1.76. The mean score of family support was 24.78 . The mean score of peer support was 24.73 .

Table 1. Sample Characteristics (continuous data)

\begin{tabular}{lccccc}
\hline \multicolumn{1}{c}{ Variable } & N & Mean & SD & Min. & Max. \\
\hline "Cerdik" Healthy Behaviour & 200 & 31.87 & 4.71 & 17 & 43 \\
Age (years) & 200 & 61.43 & 8.91 & 42 & 80 \\
Prolanis & 200 & 1.76 & 0.78 & 0 & 3 \\
Family support & 200 & 24.78 & 4.70 & 10 & 34 \\
Peer support & 200 & 24.43 & 5.40 & 10 & 34 \\
\hline
\end{tabular}

Table 2 shows a correlation between sex and "CERDIK" healthy behavior for hypertensive patients. Female hypertensive patients had the possibility to conduct "CERDIK" healthy behavior 2.08 times than male hypertensive patients. $(\mathrm{OR}=2.08 ; \mathrm{p}=0.014)$.

\section{The result of Bivariate Analysis}

Table 2 shows that there was a correlation between education and "CERDIK" healthy 
behavior for hypertension patients. Hypertensive patients with education level $\geq$ Senior High School had the possibility to conduct "CERDIK" healthy behavior 5.49 times than hypertensive patients with education level $<$ Senior High School (OR= 5.49; $\mathrm{p}<0.001)$.

Table 2 shows that there was a correlation between Prolanis and the "CERDIK" healthy behavior in hypertension patients. Hypertensive patients who actively participated in Prolanis activities were 69.49 times (OR = 69.49; $\mathrm{p}=0.005$ ).

Table 2 shows that there was a correlation between family support and "CERDIK" healthy behavior in hypertensive patients. Hypertensive patients who received strong family support had 12.34 times more likely to conduct "CERDIK" healthy behavior than hypertensive patients who received weak family support $(\mathrm{OR}=12.34 ; \mathrm{p}<0.001)$.

Table 2 shows that there was a correlation between peer support and "CERDIK" healthy behavior in hypertensive patients. Hypertension patients who received strong peer support had 10.03 times more likely to conduct "CERDIK" healthy behavior than hypertensive patients who received weak peer support (OR=10.03; $\mathrm{p}<0.001)$.

Table 2. Chi-square test of the effect of Prolanis, sex, education, family support, friend support, on the "CERDIK" healthy behavior for hypertensive patients

\begin{tabular}{|c|c|c|c|c|c|c|}
\hline \multirow{3}{*}{ Independent Variable } & \multicolumn{4}{|c|}{ “CERDIK” Healthy Behaviour } & \multirow{3}{*}{ OR } & \multirow{3}{*}{$\mathbf{P}$} \\
\hline & \multicolumn{2}{|c|}{ No } & \multicolumn{2}{|c|}{ Yes } & & \\
\hline & $\mathbf{N}$ & $\%$ & $\mathbf{N}$ & $\%$ & & \\
\hline \multicolumn{7}{|l|}{ Sex } \\
\hline Male & 38 & 45.24 & 46 & 54.76 & 2.08 & 0.014 \\
\hline Female & 33 & 28.45 & 83 & 71.45 & & \\
\hline \multicolumn{7}{|l|}{ Education } \\
\hline$<$ Senior High School & 53 & 54.08 & 45 & 45.92 & $5 \cdot 49$ & $<0.001$ \\
\hline$\geq$ Senior High School & 18 & 17.65 & 84 & 82.35 & & \\
\hline \multicolumn{7}{|l|}{ Prolanis } \\
\hline Inactive & 64 & 81.01 & 15 & 18.99 & 69.49 & $<0.001$ \\
\hline Active & 7 & $5 \cdot 79$ & 114 & 94.21 & & \\
\hline \multicolumn{7}{|l|}{ Family support } \\
\hline $\begin{array}{l}\text { Weak } \\
\text { Strong }\end{array}$ & 14 & $\begin{array}{l}04.04 \\
12.61\end{array}$ & $\begin{array}{l}32 \\
97\end{array}$ & $\begin{array}{l}35.90 \\
87.39\end{array}$ & 4 & $<0.001$ \\
\hline \multicolumn{7}{|l|}{ Peer support } \\
\hline Weak & 56 & 61.54 & 35 & 28.46 & 10.03 & $<0.001$ \\
\hline Strong & 15 & 13.76 & 94 & 86.24 & & \\
\hline
\end{tabular}

\section{The result of Path Analysis}

Figure 1 shows that the "CERDIK" healthy behavior for hypertensive patients was indirectly affected by education, family support, and peer support.

Table 3 shows that there was a direct effect of active prolanis participation and education on the quality of life of breast cancer patients.

Table 3 shows that the "CERDIK" healthy behavior for hypertensive patients increased with active participation in prolanis activities $(b=5.00 ; 95 \% \mathrm{CI}=2.80$ to 7.20; $\mathrm{p}<0.001)$, higher education $(\mathrm{b}=1.52$; $95 \% \mathrm{CI}=0.48$ to $2.54 ; \mathrm{p}=0.004)$ strong family support $(b=1.38 ; 95 \% \mathrm{CI}=0.20$ to 2.57; $\mathrm{p}=0.023)$, strong peer support $(\mathrm{b}=$ $0.61 ; 95 \% \mathrm{CI}=-0.67$ to $2.51 ; \mathrm{p}=0.352)$, and female $(b=2.8 ; 95 \% \mathrm{CI}=-5.01$ to $-0.64 ; \mathrm{p}=$ o.011). 


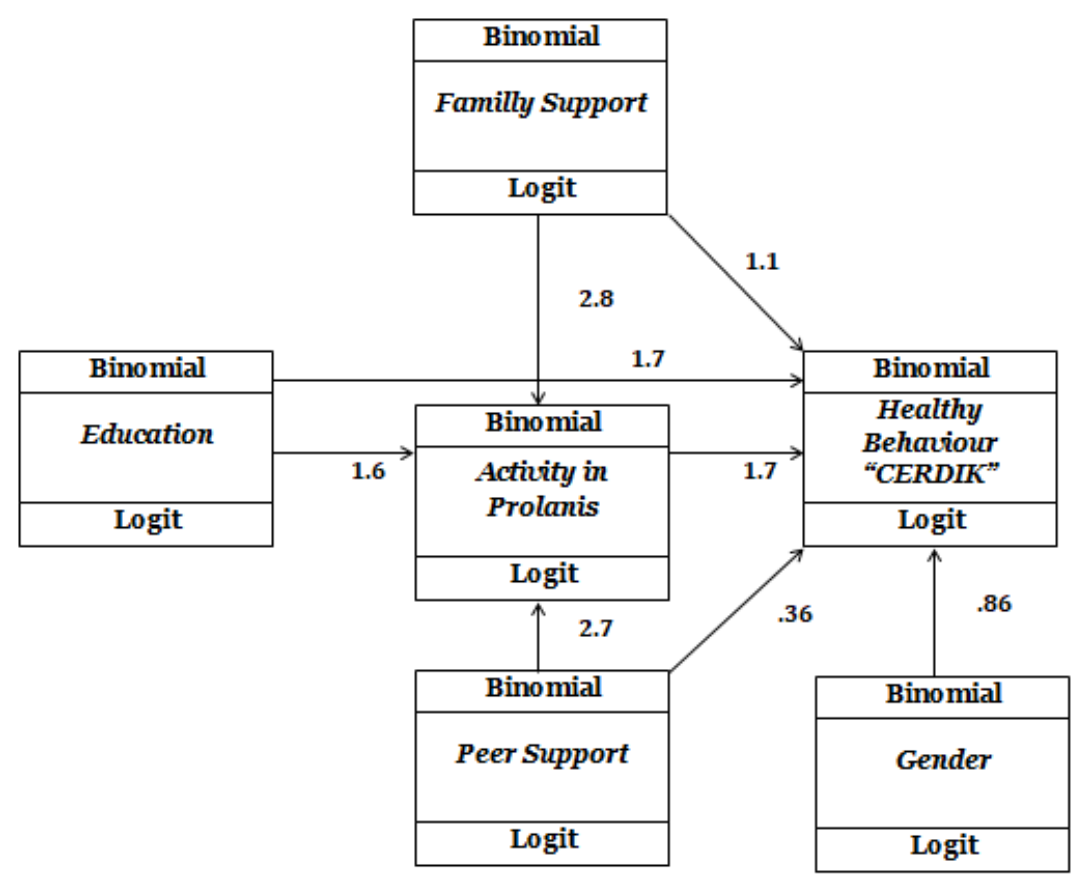

Figure 1. The model structure of path analysis

Table 3. The Results of the Effectiveness Path Analysis of Chronic Disease Management Program on "CERDIK" Healthy Behavior for Hypertension Patients

\begin{tabular}{|c|c|c|c|c|c|c|}
\hline \multirow{2}{*}{$\begin{array}{c}\text { Dependent } \\
\text { Variable }\end{array}$} & & \multirow{2}{*}{$\begin{array}{l}\text { Independent } \\
\text { Variable }\end{array}$} & \multirow{2}{*}{$\begin{array}{l}\text { Regression } \\
\text { Coef. (b) }\end{array}$} & \multicolumn{2}{|c|}{ CI 95\% } & \multirow[b]{2}{*}{$\mathbf{p}$} \\
\hline & & & & $\begin{array}{c}\text { Lower } \\
\text { Limit }\end{array}$ & $\begin{array}{l}\text { Upper } \\
\text { Limit }\end{array}$ & \\
\hline \multicolumn{7}{|l|}{ Direct effect } \\
\hline "CERDIK" & $\leftarrow$ & Prolanis (Active) & 5.00 & 2.80 & 7.20 & $<0.001$ \\
\hline Healthy & $\leftarrow$ & Education ( $\geq$ Senior High & 1.52 & 0.48 & 2.54 & 0.004 \\
\hline \multirow[t]{3}{*}{ Behavior (Yes) } & & $\begin{array}{l}\text { School) } \\
\text { (amily Sunnor }\end{array}$ & & & & \\
\hline & & Family Support ( & 1.38 & 0.20 & 2.57 & 0.023 \\
\hline & & $\begin{array}{l}\text { Peer Support (Strong) } \\
\text { Sex (Female) }\end{array}$ & $\begin{array}{l}0.61 \\
2.8\end{array}$ & $\begin{array}{l}-0.67 \\
-5.01\end{array}$ & $\begin{array}{l}1.91 \\
-0.64\end{array}$ & $\begin{array}{l}0.35^{2} \\
0.011\end{array}$ \\
\hline \multicolumn{7}{|l|}{ Indirect effect } \\
\hline $\begin{array}{l}\text { Prolanis } \\
\text { (Active) }\end{array}$ & & $\begin{array}{l}\text { Education ( } \geq \text { Senior High } \\
\text { School) }\end{array}$ & 1.60 & 0.67 & 2.51 & 0.001 \\
\hline & & Family Support (Strong) & 2.78 & 1.85 & 3.70 & $<0.001$ \\
\hline & $\leftarrow$ & Peer Support (Strong) & 2.70 & 1.78 & 3.61 & $<0.001$ \\
\hline $\begin{array}{l}\mathrm{N} \text { observatior } \\
\mathrm{AIC}=255.13 \\
\mathrm{BIC}=288.11\end{array}$ & & & & & & \\
\hline
\end{tabular}

\section{DISCUSSION}

1. The Effect of Prolanis on Quality of Life

This study shows that there is a correlation between Prolanis and "CERDIK" healthy behavior for hypertension patients. Hypertensive patients who were active in Prolanis were 5 units more likely (log odd) to conduct
"CERDIK" healthy behavior than hypertensive patients who were not active in Prolanis $(\mathrm{b}=5.00 ; 95 \% \mathrm{CI}=2.80$ to $7.20 ; \mathrm{p}=<0.0-$ o1).

This study's results are in line with a study conducted by Donnell et al. (2016), which stated that the prevention and control program for hypertension and stroke has a 
significant effect at the global level. The study was conducted in 32 countries in Asia, America, Europe, Australia, Middle East, and Africa $(\mathrm{OR}=2.98 ; 95 \% \mathrm{CI}=2.72$ to 3.28 ; $\mathrm{PAR}=47.9 \% ; 95 \%=\mathrm{CI} 45.1$ to 50.6$)$.

This health program, which is devoted to chronic diseases, especially in hypertension, has various activities, including monitoring the sodium diet, physical activity, and regular health checks. Hypertensive patients who are active in Prolanis activities will be more obedient and conduct "CERDIK" healthy behavior because there is already a schedule of activities that must be followed.

Physical activity affects blood pressure control in hypertensive patients. Someone with regular physical activity will find it easier to control their blood pressure than people who have low physical activity (Karatzi et al., 2018).

\section{The Effect of Education on "CER- DIK" Healthy Behavior}

This study shows that there is a correlation between education and "CERDIK" healthy behavior. Hypertensive patients with education level $\geq$ Senior High School had a likelihood (log odds) of conducting "CERDIK" healthy behavior 1.52 units greater than hypertensive patients with education level $<$ Senior High School ( $b=1.52 ; 95 \%$ CI $=0.48$ to $2.54 ; \mathrm{p}=0.004)$. This study is in line with the study conducted by Chiara et al. (2017), which stated that education is inversely proportional to people's healthy behavior with cardiovascular disease. Patients with cardiovascular disease with low education pay less attention to healthy behavior $(\mathrm{OR}=0.45 ; \mathrm{p}=$ o.001).

Riberrio et al. (2016) argued that one of the obstacles to promotive and preventive action for CVD disease is the low level of education. Low levels of education can affect the delivery of cardiovascular disease prevention information.
The prevalence of hypertension is higher when associated with education level ( $\mathrm{p}<0.05$ ). With a low education level, someone has a low awareness of healthy life behavior. (Su et al., 2019). The low awareness of a healthy lifestyle for people with hypertension is also affected by the low education level. With low education, someone has low obedience to healthy diet behavior (Yen, 2017)

Ferreira (2019) described that in Brazil, low levels of education increase the risk of hypertension.

\section{The Effect of Family Support on "CERDIK" Healthy Behavior}

The results showed that there was a correlation between family support and "CERDIK" healthy behavior. Hypertensive patients with education level $\geq$ Senior High School have the likelihood (log odds) of conducting "CERDIK" healthy behavior 1.38 units greater than hypertensive patients who received weak family support $(b=1.38 ; 95 \% \mathrm{CI}=0.20$ to 2.57; $\mathrm{p}=0.023$ ).

The results show that interventions involving family members will have a greater impact on CVD patients' healthy behavior, including a healthy diet, health checks, and regular exercise (Yang et al., 2019).

The source of family support is the most accessible in managing hypertension (Adisa et al., 2017). Family support plays a very important role in physical activities $(\mathrm{OR}=$ 0.04; 95\% CI= 0.02 to 0.09), a significant factor predicting regular exercise in hypertensive patients (Zhang et al., 2020)

\section{The Effect of Peer Support on "CERDIK" Healthy Behavior}

The results show that there is a correlation between peer support and "CERDIK" healthy behavior. Hypertensive patients who received strong peer support had a probability (log odd) to conduct "CERDIK" healthy behavior 0.61 unit greater than hypertension patients who received weak peer support $(b=0.61$; $95 \% \mathrm{CI}=-0.67$ to $2.51 ; \mathrm{p}=0.352$ ). 
A study conducted by Nelson et al. (2018) stated that the results of peer support programs are considered effective for providing community-based prevention services to patients in areas at high risk of cardiovascular disease. The peer support program has a positive impact $(\mathrm{p}<0.001)$ on obedience to treatment regimens in patients with hypertension (Haidari et al., 2017).

Positive perceptions of peer support and a greater understanding of the potential reasons why healthy behavior change can be an effective strategy for African-American men (Lee et al., 2018).

\section{The Effect of Sex on "CERDIK" Heal- thy Behavior}

The results showed that sex affected "CERDIK" healthy behavior. Female hypertensive patients have the possibility (log odds) to conduct "CERDIK" healthy behaviour 2.8 units greater than male hypertensive patients $(b=2.8 ; 95 \% \mathrm{CI}=-5.01$ to $-0.64 ; \mathrm{p}=0.011)$.

Sex and physical inactivity contribute significantly to the development of hypertension. Prevention and treatment intervention programs must be implemented by considering age and gender (Kandpal et al., 2016).

A study conducted by Kagaruki (2018) with a sample of PLWHA suggested that sex affects the desire to carry out physical activity. Women have a low desire to carry out physical activity in preventing hypertension $(\mathrm{OR}=2.0 ; 95 \% \mathrm{CI}=1.2$ to 2.9$)$. Korean women with low economic status tend to have high-risk factors for hypertension, such as obesity and smoking behavior (Kim et al., 2016).

A study conducted by Daneshmand et al. (2017) in their logistic regression results found that only sex has a significant correlation with low activity behavior in hypertensive patients $(\mathrm{OR}=3.08)$.

\section{The Indirect Effect on "CERDIK" Healthy Behavior \\ a. The Effect of Education on "CER- DIK" Healthy Behavior}

This study indicates that there is an indirect effect of higher education on "CERDIK" healthy behavior through prolanis.

Individuals with hypertension with higher education perform better prevention and lifestyle improvement than male with low education. $(\mathrm{OR}=2.86 ; 95 \% \mathrm{CI}=1.96$ to 4.17) and women $(\mathrm{OR}=2.36 ; 95 \% \mathrm{CI}=1.67$ up to 3.33) (Goryoda et al, 2018).

Higher education levels are associated with a reduced risk of MS ( $\mathrm{p}=0.001)$ with $\mathrm{OR}=0.53$ (95\% CI 0.41 to 0.68 ) when comparing those with the highest and lowest education level. This correlation was only moderately reduced after adjusting for known risk factors (OR $=0.61 ; 95 \% \mathrm{CI}=0.44$ to 0.83 ). Estimates remain the same when cases with disease onset before age 28 are excluded (Bjørnevik et al., 2016).

\section{b. The Effect of Family Support on "CERDIK" Healthy Behavior}

The results show that there is an indirect effect of family support on "CERDIK" healthy behavior through prolanis.

Living with family and having family support lowered the risk factors for high blood pressure by an average of 1.91 points with organized institutions (Uchmanowicz et al., 2018).

Family support is significantly associated with hypertension self-care behavior. Interventions to improve hypertension selfcare behavior among Saudi men focus on increasing their self-confidence to engage in certain healthy behaviors. Family support can also contribute to the performance of hypertension self-care behavior (Bahari et al., 2019). 


\section{c. The Effect of Peer Support on "CER- DIK" Healthy Behavior}

The results show that there is an indirect effect of peer support on the "CERDIK" healthy behavior of hypertensive patients through prolanis.

This is in line with a study conducted by Marshall et al. (2018), which stated that low peer support is negatively associated with uncontrolled hypertensive patients $(\mathrm{OR}=0.4$; 95\% CI $=0.2$ to 0.9 ).

Peer support helps chronic disease patients be treated by (1) conveying hope and providing ways of coping in situations where hopelessness is frequent, thereby protecting against unhealthy stress; (2) being someone who has had similar experiences of illness and treatment and thus provides a framework for positive social comparison; and (3) being an essential supplement for families and health care providers.

Hypertension patients who have strong peer support when visiting the prolanis will have an increased willingness to conduct "CERDIK" healthy behavior compared to hypertensive patients who do not visit the prolanis. Prolanis itself has excellent benefits for hypertensive patients who are active in its activities. For example, routine blood pressure checks, sodium diet education, home visits, and scheduled exercises.

\section{AUTHOR CONTRIBUTION}

Tri Puji Pangesti was the main researcher who collected data of the study, formulated study articles and processed data. Didik Tamtomo played a role in the formulation of the background. Bhisma Murti assisted in formulating the study framework and discussion.

\section{CONFLICT OF INTEREST}

There is no conflict of interest in this study.

\section{FUNDING AND SPONSORSHIP}

This study used the authors' funds.

\section{ACKNOWLEDGEMENT}

The authors would like to express their gratitude to the head of the Gunungkidul district health office to help this study be carried out and to all patients who have been willing to be the respondents of the study.

\section{REFERENCE}

Adisa R, Olajide OO, \& Fakeye TO. (2017). Social Support, Treatment Adherence and Outcome among Hypertensive and Type 2 Diabetes Patients in Ambulatory Care Settings in southwestern Nigeria. Ghana Med J, 51(2), 64-77.

Haidari A, Moeini E, Khosravi A. (2017). The Impact of Peer Support Program on Adherence to the Treatment Regimen in Patients with Hypertension : A Randomized Clinical Trial Study. Iran J Nurs Midwifery Res. https://doi.org/10.4103/ijn-mr.IJNMR

Bahari G, Krall J, Mallinson RK, \& Weinstein AA. (2019). Mediating role of self - efficacy in the relationship between family social support and hypertension self care behaviours : A cross-sectional study of Saudi men with hypertension. Int J Nurs Pract. https://doi.org/10.1111/ijn.12785

Bjørnevik K, Riise T. Cortese M, Holmøy T, Kampman MT, Magalhaes S, Pugliatti M. (2016). Level of education and multiple sclerosis risk after adjustment for known risk factors : The EnvIMS study. (Figure 1). MULT SCLER J. 104-111. https://doi.org/10.1177/1352458515579444

Daneshmandi H, Choobineh A, Ghaem H, \& Karimi M. (2017). Lifestyle Adverse Effects of Prolonged Sitting Behavior on the General Health of Office Workers. Am J Lifestyle Med, 7(2), 69-75. 
Dinkes DIY (2017). Profil kesehatan provinsi daerah istimewa yogyakarta tahun 2017. Dinas Kesehatan DIY. Retrieved from http://www.depkes.go.-id/resources/download/profil/PROFIL_KES_PROVINSI_2017/14_DIY_2017.pdf

Donnell MJO, Chin SL, Rangarajan S, Xavier D, Liu L, Zhang H, Zhang X. (2016). Global and regional eff ects of potentially modifi able risk factors associated with acute stroke in 32 countries ( INTERSTROKE ): a case-control study. The Lancet, 1-15. https://doi.org/10.1016/So140-6736(16)30506-2

Ferreira A, Szwarcwald CL, Damacena GN. (2013). Prevalence of obesity and associated factors in the Brazilian population : a study of data from the $2013 \mathrm{Na-}$ tional Health Survey. Rev. bras. Epidemiol. https://doi.org/10.1590/1980-549720190024

Goryoda S, Nishi N, Hozawa A, Yoshita K, Arai Y, Kondo K, Ohkubo T (2018). In a Representative Japanese Population: NIPPON DATA 2010. J Epidemiol. https://doi.org/10.2188/jea.-JE20170254 .

Idris F (2014). Panduan praktis PROLANIS (Program pengelolaan penyakit kronis). BPJS Kesehatan, 3-6.

Kim YJ, Lee JS, Park J, Choi DS, Kim DM, Lee K, Lee J (2017). Trends in socioeconomic inequalities in five major risk factors for cardiovascular disease in the Korean population : a cross-sectional study using data from the Korea National Health and Nutrition Examination Survey , 2001-2014. BMJ Open. https://doi.org-/10.1136/bmjopen-2016-014070

Kandpal V, Sachdeva MP, Saraswathy KN (2020). An assessment study of CVD related risk factors in a tribal population of India. BMC Public Health,
(2016), 1-8. https://doi.org-/10.1186/s12889-016-3106-x

Karatzi K, Moschonis G, Botelli S, Androutsos O, George P, Lionis C, \& Manios Y. (2018). Physical activity and sedentary behavior thresholds for identifying childhood hypertension and its phenoltypes: The Healthy Growth Study. J Am Soc Hypertens. https://doi.org/10.1016/j.jash.2018.07.001

Lee S. (2018). Power of Peer Support to Change Health Behavior to Reduce Risks for Heart Disease and Stroke for African American Men in a Faith-Based Community. J Racial Ethn Health Disparities. https://doi.org/10.1007/s40615-018-0460-7

Marshall IJ, Wolfe CDA \& Mckevitt C. (2018). 'People like you ?': how people with hypertension make sense of future cardiovascular risk - a qualitative study. BMJ Open. https://doi.org/10.1136/bmjopen-2018-023726.

Murti B (2018). Prinsip dan Metode Riset Epidemiologi Edisi ke Empat. Jawa Tengah. Bintang Fajar Offset

Nelson K, Gray KE, Williams JL, Lutton MC, Silverman J, Jain K, Vanderwarker C. (2019). Veteran peer Coaches Optimizing and Advancing Cardiac Health ( Vet- $\mathrm{COACH}$ ); design and rationale for a randomized controlled trial of peer support among Veterans with poorly controlled hypertension and other CVD risks. Contemp Clin Trials. https://doi.org/10.1016/j.cct.2018.08.011

Peraturan Presiden No. 72 Tahun 2012 tentang Sistem Kesehatan Nasional

Riskesdes (2018). Laporan Nasional Riskesdas 2018. In Jakarta: Badan Penelitian dan Pengembangan Kesehatan Departemen Kesehatan Republik Indonesia.

Ribeiro ALP, Duncan BB, Brant LCC, Lotufo PA, Mill JG, Barreto SM (2016). Global burden of cardiovascular disease 
cardiovascular health in Brazil Trends and Perspectives. Circulation. https://doi.org/10.1161/-CIRCULATIONAHA.114.008727.

Su J, Cui L, Du WC, Miao WG, Zhou JY, Zhou YL, Qin Y (2019). Prevalence, awareness, treatment and control of hypertension in adult residents in Jiangsu province. Europe PMC. https://doi.org/10.3760/cma.j.issn.0254-6450.2019.09.023.

Uchmanowicz J, Froelicher ES (2018). Factors influencing adherence to treatment in older adults with hypertension. Clin Interv Aging. https://doi.org/10.2147/CIA.S182881.

World Health Organization (2015). Global brief hypertension. Accessed October 2019. Retrieved from: http://www.who.int/nmh/publication/fact_sheet_cardiovascular_en.-pdf?ua $=17$.

Yao Q Liu C Zhang Y \& Xu L. (2019). Healthrelated quality of life of people with self-reported hypertension: A national cross-sectional survey in China. Int $\mathrm{J}$ Environ Res Public Health, 16(10): 124. https://doi.org/10.339o-/ijerph16101721.

Yang TJ, Cooper LA, Boulware LE, Thornton RLJ (2019). Leveraging delivery of blood pressure control interventions among low-income African American Adults : Opportunities to increase social support and produce family - level behavior change. Ethn Dis. https://doi.org/10.18865/ed.29.4.549

Yang Z, Zhao Q, Jiang P, Zheng S, \& Xu B. (2017). Prevalence and control of hypertension among a Community of Elderly Population in Changning District of shanghai : a cross- sectional study. BMC Geriatric. https://doi.org/10.1186/s12877-017-0686-y.

Yen ST, Tan AKG, Mutapha FI (2017). Awareness of diabetes , hypertension , and hypercholesterolemia in Malaysia. J Diabetes. https://doi.org/10.1111-/1753-0407.12502. 